\title{
Design of a Nondispersive Vacuum Ultraviolet Photometer and Its Application to Technical Gas Analysis ${ }^{\dagger}$ \\ Hisao Konosu*, Yo-ichiro Mashiko* and Masato SAto** \\ * Government Chemical Industrial Research Institute, Tokyo ; Hon-machi, Shibuya-ku, Tokyo, Japan \\ ** Japan Oxygen Co., Ltd.; Yokokurashinden, Oyama-shi, Tochigi, Japan
}

A nondispersive vacuum ultraviolet photometer has been developed for continuously recording the concentration of two component gaseous or liquid systems. It is essentially a single-beam instrument using the nondispersion principle. The photometer measures the relative intensities in the wavelength range of $1650 \sim 2000 \AA$ between the reference gas $\left(\mathrm{N}_{2}\right.$ or air) and the sample gas. The main apparatus consists of a deuterium discharge tube, a gas cell of $200 \mathrm{~mm}$ length with quartz windows, a photomultiplier, and a vacuum system. In the detection system a sodium salicylate plate is employed, and then the photocurrent at the detector is amplified and recorded. The ultraviolet light from the source is cut off by a fixed grating and a exit slit. Using this photometer, the following amounts(vol\%) of gases could be determined: $0.0002 \sim 0.5$ of $\mathrm{NO}_{2} ; 0.0005 \sim 0.4$ of $\mathrm{NO} ; 0.006 \sim 1$ of $\mathrm{O}_{2} ; 0.09 \sim 16$ of $\mathrm{CO}_{2} ; 0.0002 \sim 0.12$ of $\mathrm{CH}_{2}=\mathrm{CH}_{2} ; 0.0001 \sim 0.09$ of $\mathrm{CH}_{3} \mathrm{CH}=\mathrm{CH}_{2} ; 0.002 \sim 1.3$ of $\mathrm{HC} \equiv \mathrm{CH} ; 0.08 \sim 60$ of $\mathrm{CH}_{8} \mathrm{CH}_{2} \mathrm{CH}_{3}$; $0.00003 \sim 0.05$ of $\mathrm{C}_{6} \mathrm{H}_{6}$; and $0.00003 \sim 0.03$ of $\mathrm{C}_{6} \mathrm{H}_{8} \mathrm{CH}_{3}$. The coefficient of variation was less than $1 \%$. The deviation of the method was approximately $\pm 4 \%$. The precision of the photometer is comparable with that of a few other instrumental analyses. The method may be applied to the continuous analysis of chemical processes and toxic gases in the atmosphere.

$\dagger$ Technical Analyses by Optical Methods. XIX.

（日本化学会誌, 1972, p. 53 59)

\section{非分散型真空紫外光度計による無機塩および \\ アミノ酸の迅速定量法"1)}

\author{
（1971 年 7 月 22 日受理）
}

\author{
鴻笨 久雄**佐藤 正 人**. 益子 洋一郎*
}

\begin{abstract}
さきに開発した非分散型真空柴外光度計を水溶液中の無機塩およびフミノ酸の定量に応用した。本法は溶媒（水）

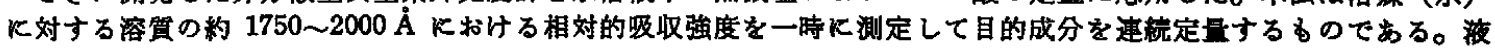

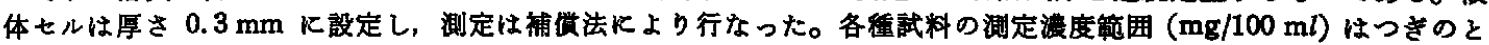
拈りである。チオシフン酸カリウム $0.04 \sim 14$, 過マンガン酸カリウム $0.05 \sim 16$, 莫化カリウム特よびョ化カリウ

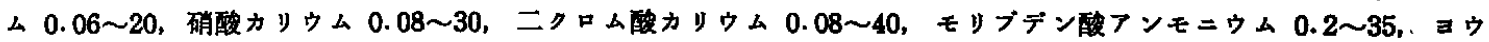

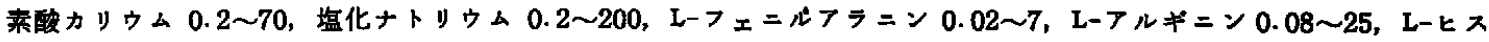

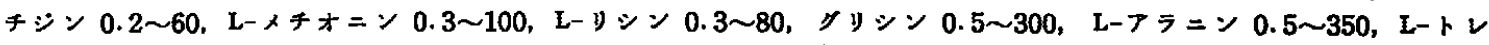

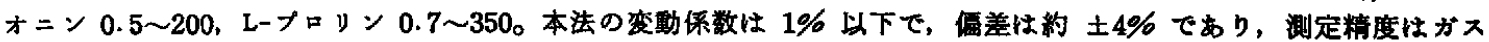
分析の場合と同等であった。以上により，本光度神は製造工業その他における各種 2 成分系液体陚料の速綪分析にる 有奻であることがかかった。
\end{abstract}

\section{1 楮 言}

さきに非分散型真空紫外光度計を試作してガス分析へ応用し， 工業分析計として適用できることを明確にしだ2。引きつづき本 光度計の溶液法への応用を試みた。従来の真空紫外分光光度法で

1）この報文を“光学法による工業分析法の研究(第 20 報)” する.

2）前報(第 19 報), 鴻监久雄, 益子洋一郎, 佐藤正人, 日化, 1972, 47 .

* 工業技街院東京工業試験所, “東京都泚谷区本町

** 日本酸案株式会社小山第二工埥, 栃木県小山市横合新田
は，透過性のよい溶媒がきわめて少なく，また厚さの非常に薄い 液体せル(これには作製上の制約をとすなら) を必要とし8)，かつ 湘定操作や方法の䋣瞧さすあって液体成分の定王江非常に面倒で ありまた一般には実施されていない。

本法恃真空紫外分光光度法と異なり，溶媒（ここでは水）飞対

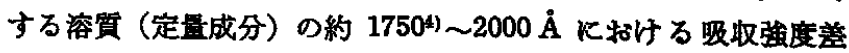
を積分払大して溳定し，定量成分湛度を求めるるのである。した

3) W. I. Kaye, Appl. Spectroscopy, 15, 130(1961).

4) R. E. Verrall, W. A. Senior, J. Chem. Phys., 50, 2746 (1969). 
がって，溶筫の相対的吸取強度が溶媒のそれより大である 2 成分 系試料であれば定量可能であるから適用範囲が広いこと，液体七 ルは真空紫外分光光度訫の場合と構造および設置法を異にし，か つ厚さ $1 \mathrm{~mm}$ 前後でよいので難点がないこと, 測定操作や方法 が簡単で，連続分析ができることなどの利点を有する。そこで夜 体用可变セルを試作じ，分析例としては工菜薬品として重要な 無譏塩，ならびにタンパク貿, 生化学, アミノ酸工業の分野で定 量の要求度の高いアミノ酸を選び測定することにした。これらの 成分のらちには通常の紫外部に吸収帯をるつるのもあるが，多く はこの測定波長範囲に特有の喛収带をるつるのであり，またバッ クグラウンドすガス分析の場合より小さいので，試料は高感度で 测定できると考えられる。

本研究では海液法にお゙ける測定条件および性能を検討したのち， 上記㢦料を測定した。その結果，真空紫外領域における光吸収を 利用した 2 成分系液体跔料の分析は本光度計飞よって容易に行な らことができ，かつガス分析と同等の精度で迅速定旦できること がわかったので報告する。

\section{2 浓体セルおよひ試菜}

\section{1 液体七ル}

液体用可変セルはステンレス銅製 円筒形（幅 $40 \mathrm{~mm}$, 直径

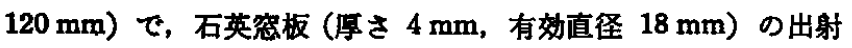
光誠外面には気体せルの場合と同様にサリチル酸ナトリウムを

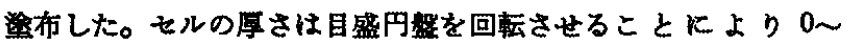
$2 \mathrm{~mm}$ (最小目盛 $0.01 \mathrm{~mm}$ ) まで連䋨可変である。またセルの上 下Kは試料の运入, 排出用として注入器が固定してあるので, 試 料は連続して流通できるはか，注射简を使用して注入することる できる。液体セルは気体セルと同じ位置に取り付け，同様に入射 光僋空板の前面までは真空系により排気される。ただし策光レン

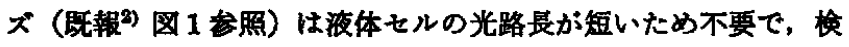
出器はセルの直後に置いた。装厤のその他の部分は既報と同一で ある。

\section{2 陚蕗}

試料として使用した試薬はヨウ菜酸カリウム（僄準試薬）のほ かは特級品である。我はイオン交掺樹脂法により精製したるのを 用いた。

\section{3 測定条件, 性能およひ測定方法}

\section{1 测定条件とその模封}

光電子增倍管に供給する定電圧直流奄源の出力電圧には，水の 透過パーセントをはぼ $100(\%)$ 飞調節するに必要な鱼高压をか け.記録計の入力電压は $1 \mathrm{~V}$ K設定した。その他の測定条件は 既報と同棣である。

まず水の相対的吸取強度を測定した。夜体せルの厚さを 0.3 $\mathrm{mm}$ K調節し，窒素を対照にして記録計の 0, 100(\%) 合わせを したとき，水の吸光度は 0.140 であった。本法ではこのように 溶媒の相対的吸収強度が弱いことから溶質は感度よく微量まで測 定できると考えられる。

つきに液体せルの厚さと誌料溶液の吸光度との関係を検討し た。試料には各種浱度の塩化マグネシウム水溶液を用い, セルの 厚さを $0.1,0.3,1.0,1.5,2.0 \mathrm{~mm} に$ にて測定した濃度一吸光度

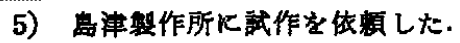

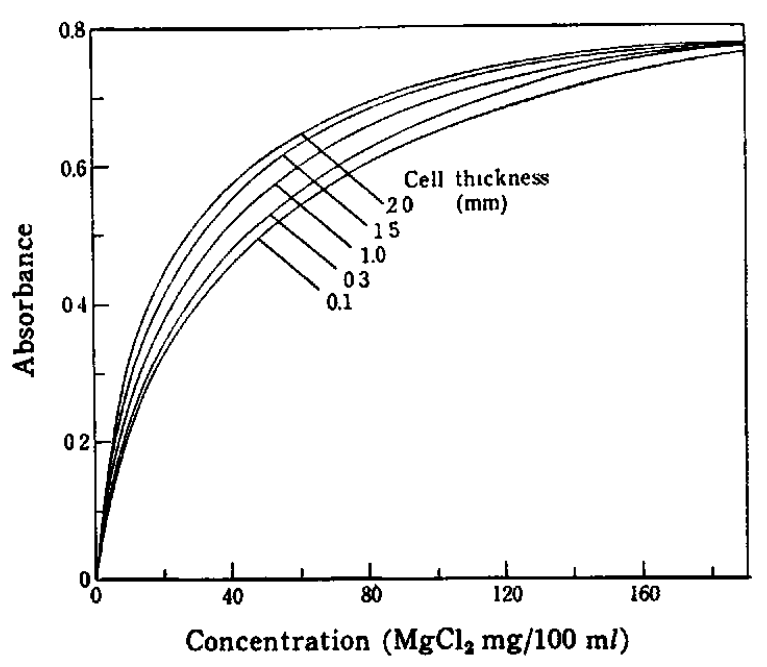

Fig. 1 Relation between cell thickness and absorbance 曲線を図 1 K示す（澌定方法は 3.3 参照)。これらの曲線の勾目 から明らかなよらに，七ルの厚さを增加させるにしたがい低瀑度 側では測定感度は向上するが，高搌度㑡では溶賀の吸取が大とな って険出器への光量が減少し, 感度は低下するので, 本法では比 较的広い湛度範囲にわたって精度よく娜定できるようにセルの厚 さは $0.3 \mathrm{~mm}$ に設定した。

また瀑度箐围は，二クロム酸カリウム水溶液を用い，記録計の

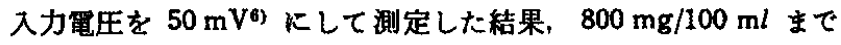
定量できた。したがって，啳に示す表 5 の淇度䇶国における上限 界は測定条件により一般に約 20 倍払大できると考えられる。

\section{2 性能漹駼結果}

溶液法に和ける性能はつぎのとおりである。たたし，既報の試 験において流量，周囲温度および電源電圧による指示変動はほと んど測定値に影整をおよぼさなかったので、これらについては省 略した。

1）再現性：士0.1\% (4.1，4.2 の測定結果による)。

2) 検出感度 : $0.1 \sim 0.5 \%$ (表 5 参照)。

3）ゼロドリフト：士1.2\%/6 hr (水を連続道入した場合)。

4) $90 \%$ 応答時間 : 約 3 秒。

5）日間変動：塩化ナトリウム水溶液を用い，表 1 に示すよう に半月間に 5 日，各 5 回透過パーセントをくり返し澌定した。こ れを一元配目により分散分析すると， $F_{0}=130.0$ **，ここで $F(4$ ， $20 ; 0.01)=4.43$ であり，日によって娜定値の翼なることが認め られた゚。

Table 1 Results of the reproducibility test

\begin{tabular}{lcccccc}
$\begin{array}{c}\text { Measuring } \\
\text { date }\end{array}$ & \multicolumn{4}{c}{ Per cent transmission(\%) } & \multicolumn{2}{c}{$\begin{array}{c}95 \% \text { Confidence } \\
\text { interval for }\end{array}$} \\
\cline { 2 - 7 } population mean \\
\cline { 3 - 7 } & $5: 1$ & 2 & 3 & 4 & 5 & $53.50 \pm 0.04$ \\
$2 / 23$ & 53.6 & 53.5 & 53.5 & 53.4 & 53.5 & 53.2 \\
$2 / 26$ & 53.2 & 53.2 & 53.2 & 53.2 & 53.2 & $53.20 \pm 0.04$ \\
$3 / 1$ & 53.3 & 53.3 & 53.3 & 53.3 & 53.3 & $53.30 \pm 0.04$ \\
$3 / 3$ & 53.0 & 53.0 & 53.0 & 53.0 & 52.9 & $52.98 \pm 0.04$ \\
$3 / 11$ & 53.1 & 53.1 & 53.1 & 53.1 & 53.1 & $53.10 \pm 0.04$
\end{tabular}

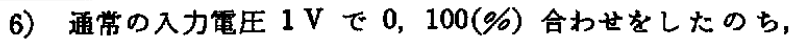
$50 \mathrm{mV}$ に切り枆えて测定した.

7）光源のスペクトルおよびサリチル酸ナトリウムの発光スベ クトルの強度变化などが湘定值に影響をおよ注すので，定 聂にさいしては基隼試料を用いてその变動を測定しておく 必要がある. 
以上の結果を気体試料を用いた場合と比㜞すると,日間変動は 少なく，再現珄，検出感度，応答時間は同程度であり，ドリフト はいくぶん大であった。

\section{3 測定方法}

测定条件を 3.1 のよ5K設定し，娜定は補償法により行なっ た。すなわち，はじめ液体セルに水を入れ，既報と同様にして記 録計の 0,100(\%) 合わせをしたのち液体セルに試料を入れれば， 溶媒の吸収は相殺されて定量成分の吸収に応じた透過パーセント が指示される。この間の所要時間は約 5 分である。検瞏線は, 各 種成分について調製した各澴度の陚料溶液の 5 回くり返し測定值 の平均値から作成した。な拉，干涉成分はあらかじめ除去する必 要がある。

\section{4 測定結果および考䆺}

\section{1無機挥の場合}

チオシフン酸カリウム, 過マンガン酸カリウム，臭化カリウム の検量線を図 2 K， ヨウ化カリウム，硝醉カリウム，二クロム酸 カリウムの恰量線を図3に，モリブデン䜵アンモニウム，ヨウ素 酸カリウム，塩化ナトリウムの検量線を図4k示寸。検量線はい ずれも低眼度では Beer の法則が成立したので, 浱度を $x(\mathbf{m g} /$ $100 \mathrm{~m} l)$, 吸光度を $y$ として回㷌直線を推定し, また Beer の法 則から離反したそれ以上の漫度では最小二乗法により二次曲線の あてはめを行なった。これらの $y$ から $x$ を推定する回熳式を図 2 〜4の下に記す（試料番号は表 2 のそれと同し)。

試料の単位浱度あたりの相対的吸収強度の順位は チオシアン

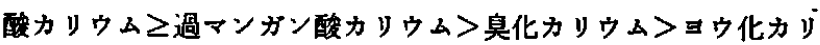
ウム>硝酸カリウムZニクャム酸カリウムフモりブデン酸アンモ

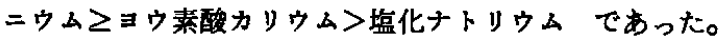
その他の無譏塩の相対的吸収強度を測定した結果8), $1 \mathrm{~g} / 100 \mathrm{ml}$

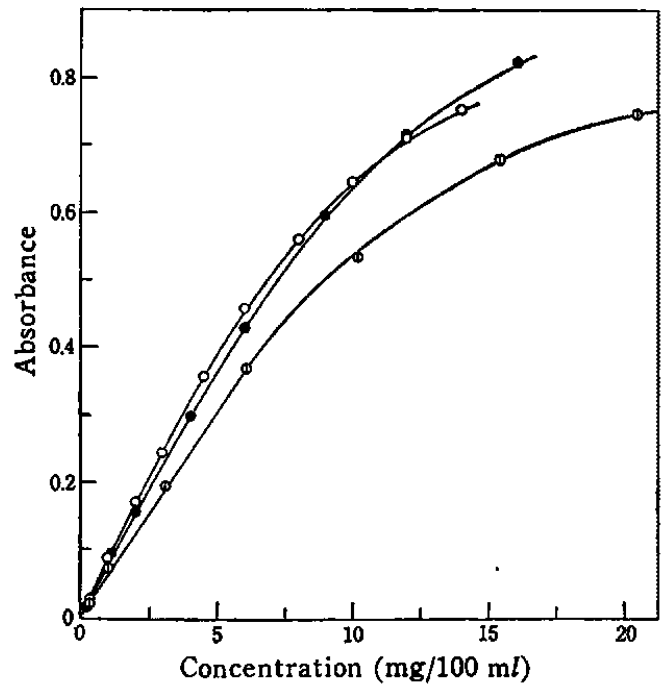

Fig. 2 Calibration curves for potassium thiocyanate, potassium permanganate, and potassium bromide

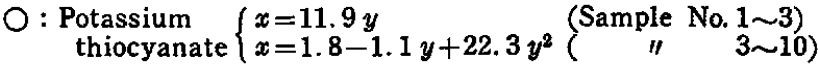
: Potassium $\{x=13.0 y \quad$ " $1 \sim 3)$
permanganate $\left\{x=1.5+1.7 y+19.0 y^{2}(\quad\right.$ " $3 \sim 8)$
(1): Potassium $\left\{\begin{array}{l}x=-0.1+16.9 y \quad(\quad) \quad 1 \sim 4) \\ x=12.4-43.3 y+72.0 y^{2}(\quad \prime \prime\end{array}\right.$

8）多くは化学的に不安定であるため，定性的な測定にとどめ た.
水溶液に和ける喛光度は亚硝酸ナトリウム 0.9 , チオ硫酸ナトリ ウム 0.8 , 水酸化ナトリウム 0.8 , 硫化ナトリウム 0.8 , ベルオ キソ二硫酸アンモニウム 0.7 であり，これらはさきの試料と同 程度であったが、アミド硫酸アンモニウム 0.4 , 硫酸カリウム

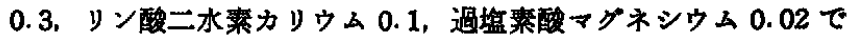

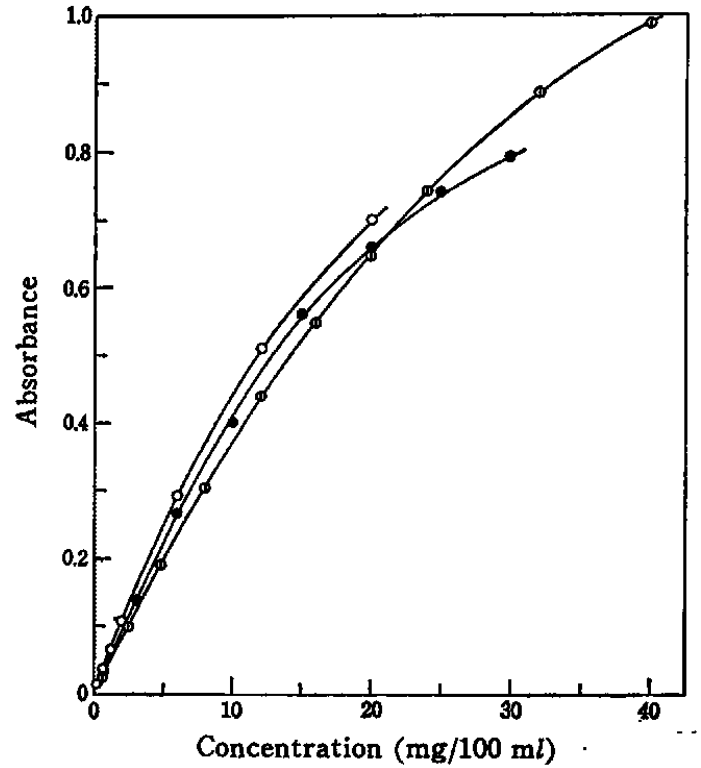

Fig. 3 Calibration curves for potassium iodide, potassium nitrate, and potassium dichromate

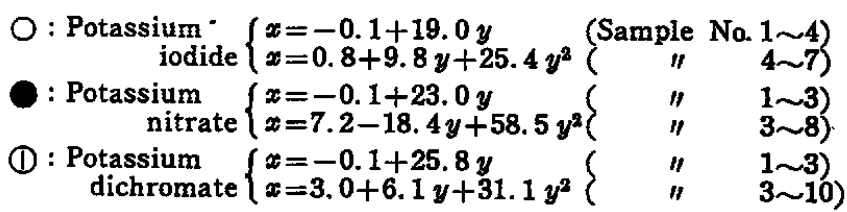
Concentration $(\mathrm{mg} / 100 \mathrm{ml})$ (II)

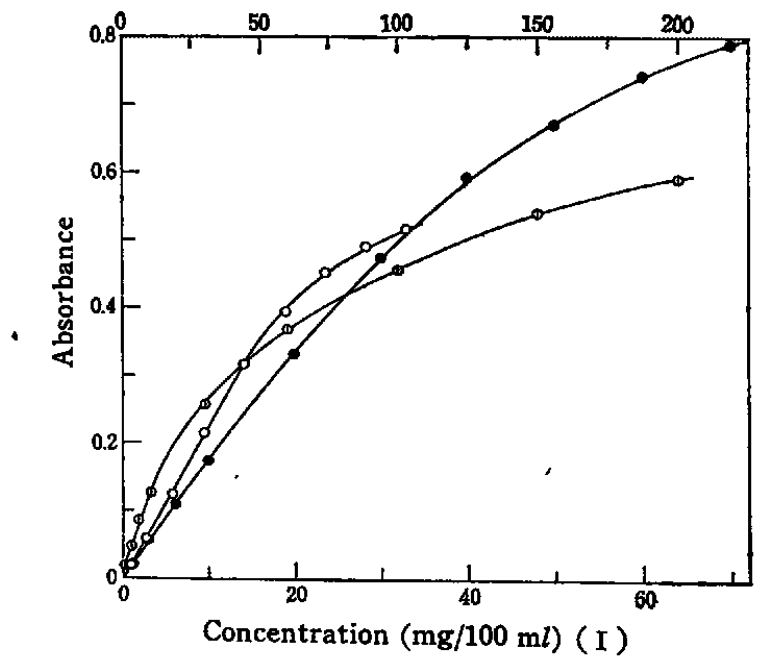

Fig. 4 Calibration curves for ammonium molybdate, potassium iodate, and sodium chloride

\begin{tabular}{|c|c|c|c|}
\hline $\begin{array}{l}\text { : Ammonium } \\
\text { molybdate (I) }\end{array}$ & $\left\{\begin{array}{l}x=0.2+44.0 y \\
x=35.2-162.5 y+\end{array}\right.$ & ample & No. 1 5) \\
\hline & & " & $5 \sim 9)$ \\
\hline $\begin{array}{l}\text { Potassium } \\
\text { iodate (I) }\end{array}$ & $\left\{\begin{array}{l}x=-0.1+56.0 y \\
x=5.3+8.5 y+89.7 y^{2}\end{array}\right.$ & " & $\begin{array}{l}\text { 1 } \sim 3) \\
3 \sim 10)\end{array}$ \\
\hline $\begin{array}{l}\text { : Sodium } \\
\text { chloride (II) }\end{array}$ & $\left\{\begin{array}{l}x=-0.8+83.0 y \\
x=27.2-229.0 y\end{array}\right.$ & $"$ & $1 \sim 4)$ \\
\hline & & $n$ & 4 9) \\
\hline
\end{tabular}


Table 3 Relation between absorbance and concentration of chloride ions Concentration of $\mathrm{Cl}^{-}(\mathrm{mg} / 100 \mathrm{ml})$

\begin{tabular}{|c|c|c|c|c|c|c|c|c|}
\hline \multirow{2}{*}{ Absorbance } & \multicolumn{8}{|c|}{$101 \quad(1) \mathrm{B} / 100$} \\
\hline & $\mathrm{NaCl}$ & $\mathrm{KCl}$ & $\mathrm{CsCl}$ & $\mathrm{MgCl}_{2}$ & $\mathrm{CaCl}_{2}$ & $\mathrm{BaCl}_{2}$ & $\mathrm{NH}_{4} \mathrm{Cl}$ & $\mathrm{FeCl}_{8}$ \\
\hline 0.05 & 1.9 & 2.0 & 1.7 & 1.8 & 2.5 & 1.6 & 2.1 & 0.9 \\
\hline 0.10 & 4.3 & 4.3 & 3.5 & 4.4 & 5.0 & 4.0 & 4.7 & 1.4 \\
\hline 0.15 & 7.2 & 7.5 & 5.7 & 7.9 & 8.5 & 7.2 & 7.5 & 2.2 \\
\hline 0.20 & 11.6 & 12.0 & 10.3 & 12.4 & 13.7 & 11.6 & 11.5 & 3.1 \\
\hline 0.25 & 17.3 & 18.0 & 16.8 & 17.9 & 20.1 & 17.7 & 17.1 & 4.1 \\
\hline 0.30 & 24.3 & 25.1 & 25.1 & 25.2 & 27.8 & 26.5 & 24.2 & 5.2 \\
\hline 0.35 & 33.1 & 33.4 & 37.2 & 36.3 & 37.3 & 38.1 & 33.5 & 6.6 \\
\hline 0.40 & 44.2 & 43.5 & 54.9 & 53.1 & 51.0 & 59.1 & 45.1 & 8.0 \\
\hline 0.45 & 58.4 & 55.9 & & 73.7 & 67.0 & & 60.2 & 9.9 \\
\hline 0.50 & 75.2 & 71.4 & & & 85.0 & & 80.1 & 12.3 \\
\hline 0.55 & 95.2 & & & & 108.4 & & 104.2 & 15.6 \\
\hline
\end{tabular}

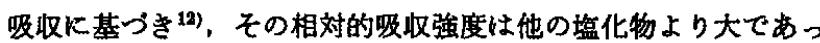
た。

なお，四収極大波長に拊るモル吸光係数は塩素イオンでは $10000(1810 \AA$ A $)$, 臭素イオンでは $12000(1900 \AA ̊ 丿)$ 括よび 11000

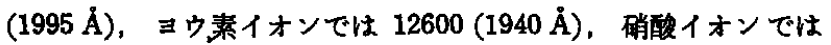
$8800(1936 \AA \AA$ ) $)$ であり らの塩の相対的吸収強度の順位と対応している。

\section{2 アミノ酸の坦合}

L-フェニルアラニン, L-アルギニン, L-ヒスチジンの検量線を 図 5 K，L-メチオニン，L-リシン，グリシンの検量線を図 6 K， Lーアラニン，L-トレオニン, L-プロリンの検量線を図 7 k示す。 これらの検量線は無機塩の場合と同様，低漕度において Beerの - Concentration (mg/100 ml) (II)

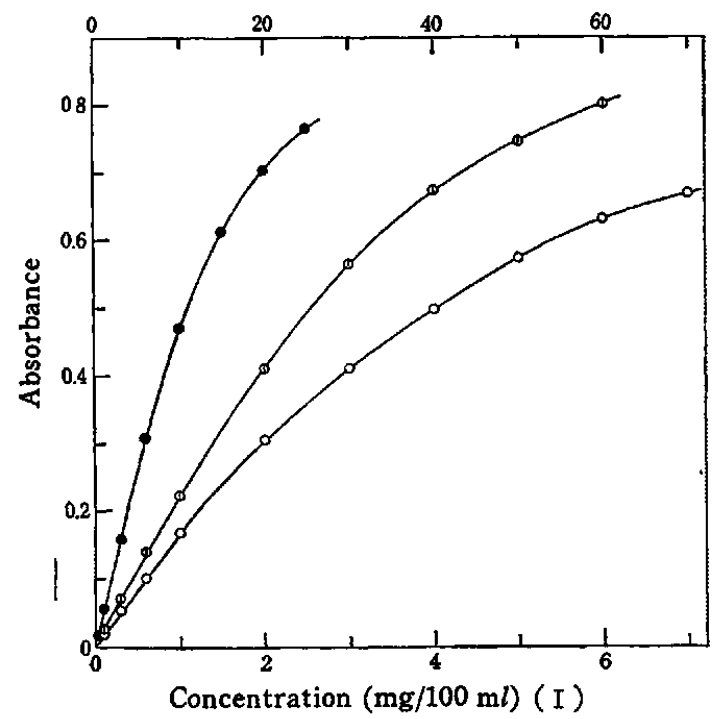

Fig. 5 Calibration curves for L-phenylalanine, Larginine, and L-histidine

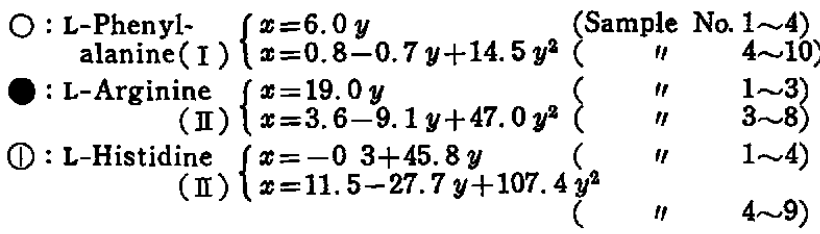

12) M. G. Evans, M. Santappa, N. Uri, J. Polym. Sci., 7, 243(1951) ; 坪村 宏, “励起状態の化学, 井本 棇䌁, 講 坐有機反応機椿 12 "，東京化学同人(1967)p. 152.

13) S. F. Mason, Quart. Rev., 15, 287(1961).
法則が成立し，それ以上の濃度では Beer の法則から離反したの

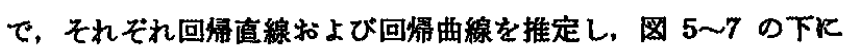
記した（試料番号は表 4 のそれと同じ)。

試料のらち，芳香環，複素環，イオウ原子をるつもの，ならび にジアミノモノカルボン酸は哷収強度が大であり，単位濃度あた

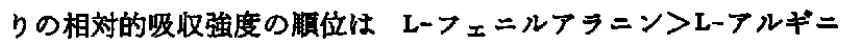
ソ>L-ヒスチジン>L-メチオニン>Lーリシス>グリシン $Z \mathrm{~L}-\boldsymbol{L}$ ラニン ZL-トレオニン>L-プロリン であった。この順㕸は真空 紫外吸収スペクトル14からの推定とよく対応している。これから 類推して，タンパク質を棈成するアミノ酸の相対的吸収強度は一

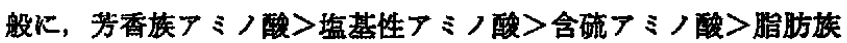
モノアミノモノカルボン酸乙脂肪族オキシナミノ酸>イミノカル ボン酸 の順であろらと考えられる。また酸性厂ミノ酸および酸 性アミノ酸アミドは測定していないが, 前者はその吸取スペクト ル14かか含硫アミノ酸と同程度の相対的吸収強度と推定される。

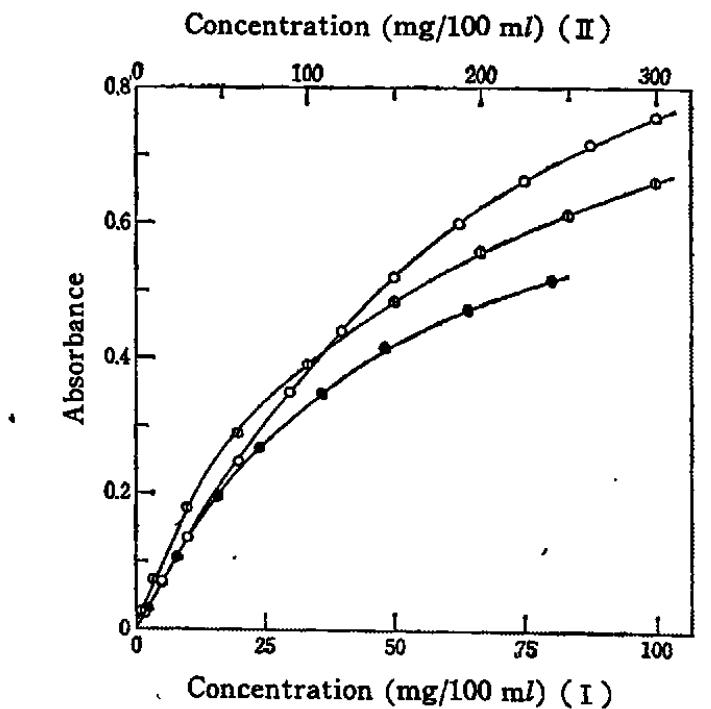

Fig. 6 Calibration curves for L-methionine, L-lysine, and glycine

O : L-Methio- $\{x=-0.2+75.4 y \quad$ (Sample No. 1 3)

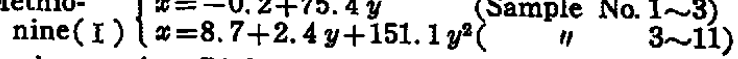

: L-Lysine $\left\{\begin{array}{lll}x=74.0 y & \\ x=9.6-38.1 y+328.0 y^{2}( & \prime \prime & 1 \sim 3\end{array}\right)$

(1): Glycine (II) $\left\{\begin{array}{l}x=-2.1+178.7 y \\ x=39.9-198.0 y+883.7 y^{2}\end{array}\left(\begin{array}{ll}1 \sim 3)\end{array}\right.\right.$

14）総説として, 厷田 㮴, Jasco Report, 5, No.2, 1(1968). 
て求めた。

Table 5 Limit of detection and measuring range for the proposed method

Measuring

Sample

$\begin{array}{cc}\begin{array}{c}\text { Limit of } \\ \text { detection } \\ (\mathrm{mg} / 100 \mathrm{ml})\end{array} & \begin{array}{c}\text { range } \\ (\mathrm{mg} /\end{array} \\ & 100 \mathrm{ml})\end{array}$

\begin{tabular}{|c|c|c|c|}
\hline & Potassium thiocyanate & 0.04 & $0 \sim 14$ \\
\hline & Potassium permanganate & 0.05 & $0 \sim 16$ \\
\hline & Potassium bromide & 0.06 & $0 \sim 20$ \\
\hline & Potassium iodide & 0.06 & $0 \sim 20$ \\
\hline $\begin{array}{r}\text { rganic } \\
\text { sal }\end{array}$ & Potassium nitrate & 0.08 & $0 \sim 30$ \\
\hline & Potassium dichromate & 0.08 & $0 \sim 40$ \\
\hline & Ammonium molybdate & 0.19 & $0 \sim 35$ \\
\hline & Potassium iodate & 0.19 & $0 \sim 70$ \\
\hline & Sodium chloride & 0.22 & $0 \sim 200$ \\
\hline & L-Phenylalanine & 0.02 & $0 \sim 7$ \\
\hline & L-Arginine & 0.08 & $0 \sim 25$ \\
\hline & $\mathrm{L}$-Histidine & 0.15 & $0 \sim 60$ \\
\hline & L-Methionine & 0.27 & $0 \sim 100$ \\
\hline acids & L-Lysine & 0.31 & $0 \sim 80$ \\
\hline & Glycine & 0.48 & $0 \sim 300$ \\
\hline & L-Alanine & 0.48 & $0 \sim 350$ \\
\hline & L-Threonine & 0.46 & $0 \sim 200$ \\
\hline & L-Proline & 0.67 & $0 \sim 350$ \\
\hline
\end{tabular}

\section{5 結}

本光度計を溶液法へ応用する目的で，剆定条件ならびに性能を 検討したのち，分析例として水溶液中の無機塩およびアミノ酸そ れぞれ 9 硬類を測定し，定量方法の確立をはかった。その結果， 変動係数は $1 \%$ 以下，愠差は䄪 $\pm 4 \%$ であり，工業分析計とし てガス分析の場合と同等の精度および性能で溶液法にす䔔用でき， 従来の真空紫外分光光度法にくらへてはるかに容易に液体試料の 定量す行なえることが明確になった。本法は高感度が得られ，微 量成分まで定量でき，かつ測定条件により比較的広い浱度範囲に わたって測定することができる。また非破壞的に連続分析ができ ろので，とくにアミノ酸の場合には従来の個別定量法と比較して いちじるしく簡易である。本法は製造工業その他における各種 2 成分系液体試料に適用できるが，大貫成分之定量成分々の相対的 吸収強度にいちしるしい差異がない試料，たとえば有栱工業薬品 中の微量不純物の定量などには不迨当である。

本研究火助言をいただいた当所第二部第一橦長久保山 昭博士 飞謝意を表する。

（1971 年 10 月, 日本化学会第 25 年会化学阅係学協会発表会 合同大会請演）

\title{
Rapid Determination of Some Inorganic Salts and Amino Acids by a Nondispersive Vacuum Ultraviolet Photometer ${ }^{\dagger}$
}

\author{
Hisao Kōnosu*, Masato S Ato** and Yo-ichiro Mashrko* \\ * Government Chemical Industrial Research Institute, Tokyo; Hon-machi, \\ Shibuya-ku, Tokyo, Japan \\ ** Japan Oxygen Co., Ltd.; Yokokurashinden, Oyama-shi, Tochigi, Japan
}

A nondispersive vacuum ultraviolet photometer, previously developed by the present authors, has been applied to the measurement of some inorganic salts and amino acids in aqueous solution. Quantitative analysis for a given component is achieved by simultaneous measurement of the relative intensity between the solvent(water) and the solute in the wavelength region about $1750 \sim 2000 \AA$. A cell was designated to $0.3 \mathrm{~mm}$ thickness and samples were determined by the compensation method. Using the method, the following amounts $(\mathrm{mg} / 100 \mathrm{ml})$ of samples could be determind; $0.04 \sim 14$ of $\mathrm{KSCN} ; 0.05 \sim 16$ of $\mathrm{KMnO}_{4} ; 0.06 \sim 20$ of $\mathrm{KBr}$ and $\mathrm{KI} ; 0.08 \sim 30$ of $\mathrm{KNO}_{3} ; 0.08 \sim 40$ of $\mathrm{K}_{2} \mathrm{Cr}_{2} \mathrm{O}_{7} ; 0.2 \sim 35$ of $\left(\mathrm{NH}_{4}\right)_{6} \mathrm{Mo}_{7} \mathrm{O}_{24} ; 0.2 \sim 70$ of $\mathrm{KIO}_{3}$; $0.02 \sim 7$ of L-Phenylalanine; $0.08 \sim 25$ of L-Arginine; $0.2 \sim 60$ of L-Histidine; $0.3 \sim 100$ of $\mathrm{L}-$ $0.2 \sim 200$ of $\mathrm{NaCl}$; Methionine; $0.3 \sim 80$ of L-Lysine; $0.5 \sim 300$ of Glycine ; $0.5 \sim 350$ of LAlanine; $0.5 \sim 200$ of $\mathrm{L}-\mathrm{Th}$ reonine ; and $0.7 \sim 350$ of L-Proline. The coefficient of variation was less than $1 \%$, which tied with that obtained by the gas analysis. The deviation of the method was approximately $\pm 4 \%$. The photometer has been proved to be effective also for continuous analysis of two component liquid samples in the process streams and others.

$\uparrow$ Technical Analyses by Optical Methods. XX. 